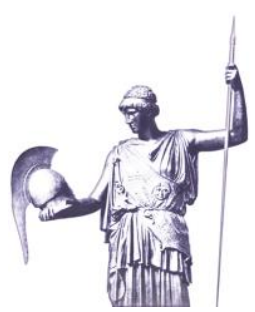

Connections: The Quarterly Journal

ISSN 1812-1098, e-ISSN1812-2973

Alessandro Scheffler Corvaja, Brigita Jeraj, Uwe M. Borghoff, Connections QJ 15, no. 1 (2016): 79-106 http://dx.doi.org/10.11610/Connections.15.1.06

Research Article

\title{
The Rise of Intelligence Studies: A Model for Germany?
}

\section{Alessandro Scheffler Corvaja, Brigita Jeraj, and Uwe M. Borghoff}

Universität der Bundeswehr München and Director of the Campus Advanced Study Center, München, Germany, https://www.unibw.de

\begin{abstract}
Intelligence Studies have established themselves as a common subject in higher education in the Anglosphere. Germany so far offers no dedicated program in the field. A postgraduate program that promotes an understanding of the role and context of intelligence, strengthens analytical skills and deepens subject-matter expertise would combine the best features of various educational models, and provide a real contribution to building a cadre of highly qualified intelligence professionals. In this research report, the authors succinctly document the state of the discipline, present examples of some twelve degree programs, and, finally, develop initial proposals for an intelligence curriculum for German universities.
\end{abstract}

Keywords: intelligence studies, curriculum, military education.

\section{Introduction}

Traditionally, universities have paid little attention to intelligence issues. Even those scholars and institutions specializing on national security and defense only scantly dealt with the intelligence. In the words of Sir Alexander Cadogan, "intelligence studies" used to present a "missing dimension" of international studies. ${ }^{1}$ This only slowly started to change in the 1980s and 90s: investigations into high-profile intelligence scandals such as Watergate and Iran-Contra, but

1 Quoted in Len Scott and Peter Jackson, "The Study of Intelligence in Theory and Practice," Intelligence \& National Security 19:2 (2004): 140. 
also the declassification of increasing amounts of intelligence files in the United States and the United Kingdom, led to a growing awareness of the important role of intelligence in international affairs. The first associations of intelligence historians emerged and the first specialized journals appeared on the market. ${ }^{2}$

However, it was not until after the events of September 11, 2001 that interest in the previously little-known discipline exploded: while in 2006, for instance, only four of the twenty-five top-universities in the United States offered courses on intelligence, this has since expanded to more than half. ${ }^{3}$ At the same time, also universities in France, Israel, Spain, and other countries began to offer coursework and even specialized programs in intelligence issues. This development was driven by researchers, intelligence agencies, and scholars alike. On the side of academics, the wide-ranging consequences of intelligence failures such as 9/11 and the subsequent invasion of Iraq sparked an increased research interest in intelligence as an important and yet underappreciated factor in national decision-making. At the same time, intelligence services themselves started to reflect on these failures and adapted the training of their officers and analysts. ${ }^{4}$ On the side of students, the salience of the subject and the promising job market accompanying the expansion of intelligence agencies has more and more students interested in building a career in the field of intelligence - and in an education that could best prepare them for this.

In a recent review of the state of the field, its most prominent exponents agree that, in the last decade, the discipline has undergone a process of professionalization and established itself as an accepted sub-discipline of security studies. Its most important current research areas include diverse topics such as intelligence failure, politicization of intelligence, questions of oversight, the ethics of intelligence and the connection between national and intelligence cultures. ${ }^{5}$ This assessment of a thriving Intelligence studies discipline, however, only holds true for the Anglophone world. It is particularly inaccurate for Germany, where intelligence remains an almost inexistent field. ${ }^{6}$

2 Martin Rudner, "Intelligence Studies in Higher Education: Capacity-Building to Meet Societal Demand," International Journal of Intelligence and Counter-Intelligence 22:1 (2008): 112.

3 Jonathan Smith, "Amateur Hour? Experience and Faculty Qualifications in U.S. Intelligence Courses," Journal of Strategic Security 6:3 (2013): 25.

4 For instance, the US Intelligence Community established "Centers of Academic Excellence" at four universities. This number has since increased to ten. See Rudner, "Intelligence Studies," 114.

5 Loch J. Johnson and Allison M. Shelton, "Thoughts on the State of Intelligence Studies: A Survey Report," Intelligence and National Security 28:1 (2013): 111.

6 As noted by one of the few scholars of the subject, Wolfgang Krieger, this absence is largely the result of three specific factors: a lack of declassified documents, the complete absence of former intelligence officials at universities-part of an overall lack of the so-called "revolving door" - and the particular mindset of German academia which is typically characterized by considerable disdain for research on defense and security issues. The history of two totalitarian regimes also means that this disdain is 
The large numbers of students looking to make a career in intelligence has also led to the emergence of "intelligence schools," particularly in the United States. While "intelligence studies" as a traditional university discipline is geared towards producing students of intelligence, these schools have a more practical focus and are trying to educate future intelligence officials - in particular, analysts. ${ }^{7}$ Instead of creating specialists whom intelligence services would then hire for their expertise, these programs - which are usually at the undergraduate or graduate level ${ }^{8}$ - focus on functional knowledge and aim to educate "generalists" who are "trained in the methods and mechanics of intelligence analysis." ${ }^{\prime \prime}$ As a consequence of the research conducted at these schools, the subject of intelligence analysis is also increasingly developing into its own sub-discipline in the field.

\section{Intelligence Education at a University?}

This leads directly to one of the most contested and important questions in the discipline: what exactly can and should universities actually offer to the intelligence community in terms of education? As discussed above, the traditional primary channel through which universities catered to the needs of intelligence services used to be the training of specialists - be they political scientists, engineers or linguists. Such education would typically be undertaken before joining the relevant agencies. The required training for specific tasks would then usually occur not at universities, but in classified environments at the in-house institutions of the intelligence services.

The emergence of programs with specific intelligence curricula in the undergraduate and graduate field, particularly at intelligence schools, is already changing this pattern. Graduates of these programs bring less specialized knowledge and more practical training and skillsets. The usefulness of these programs remains contested as critics emphasize the importance of knowledge

particularly strong in the case of intelligence. See: Wolfgang Krieger, "German Intelligence History: A Field in Search of Scholars," Intelligence and National Security 19:2 (2004): 187-189.

7 Stephen Marrin, Improving Intelligence Analysis: Bridging the Gap Between Scholarship and Practice (Routledge: London, 2011), quoted in Michael Landon-Murray, "Moving U.S. Academic Intelligence Education Forward: A Literature Inventory and Agenda," The International Journal of Intelligence and Counter Intelligence 26:4 (2013): 746.

8 For the purpose of this report, programs are divided into undergraduate, graduate and postgraduate programs. Undergraduate programs are bachelor degrees. Graduate programs are those master's programs that are designed as "consecutive" and do not require extensive previous professional work experience. Although in common use there is no systematic distinction between "graduate" and "postgraduate" programs in the US and UK, this article will refer to postgraduate (professional) programs as, instead, programs that are aimed at practitioners with significant professional experience in their field. PhD programs are not discussed in this report.

9 Landon-Murray, "Moving U.S. Academic Intelligence Education Forward," 746. 
and expertise on specific subjects over "training" in analytic tradecraft. As described by Lowenthal, "analysts are hired for a body of knowledge, not for a skill set." ${ }^{10}$ Other leading experts argue instead that such programs are essential and provide unique resources to the intelligence community. ${ }^{11}$ Another much disputed aspect is the uneven nature and quality of these programs, yet this might be typical for an emerging discipline. As can be seen, the degree to which the character of the entry-level candidates universities provide to intelligence agencies should change remains an important question in the field with the tradeoff between subject-matter expertise on specific aspects on the one hand, and general training in important intelligence techniques on the other as its most contested subject. ${ }^{12}$

Change is also under way in the field of postgraduate education, and its role in the careers of intelligence officers is becoming increasingly significant. In light of the massive intelligence failures that occurred in the early 2000s, many intelligence services began to reflect on the status of their analytical communities. While the enquiries into the $9 / 11$ attacks still mainly focused on the lack of inter-intelligence cooperation, they already complained that intelligence analysts had suffered from a "failure of imagination" and would have to challenge traditional thinking patterns. ${ }^{13}$ But the main blow to intelligence analysis came when the enquiries into intelligence failures in Iraq clearly put them in the spotlight. ${ }^{14}$ Reports about the failure emphasized a lack of analytical standards, which some blamed on the fact that "intelligence analysts [are] trained in the proper development of theoretical frameworks and research hypotheses and in advanced social-science analytic methods." ${ }^{15}$

In fact, many came to see the entire field of training and education as the greatest professional weakness of analysis. ${ }^{16}$ As a consequence, it was increasingly questioned whether the training in the intelligence services' own institutions actually created sufficient intellectual flexibility to deal with the challenges of complex modern threat environment, and whether in-house training in classified environments actually promoted sufficient analytical rigor and re-

10 Mark M. Lowenthal, "The Education and Training of Intelligence Analysts," in Analyzing Intelligence: National Security Practitioners' Perspectives, ed. Roger Z. George and James B. Bruce (Washington, DC: Georgetown University Press, 2014), 306. Landon-Murray, "Moving U.S. Academic Intelligence Education Forward," 768.

12 For an in-depth discussion, cf. ibid.

13 For a discussion of the intelligence requirements of the complex modern threat environment, see Warren Fishbein and Gregory Treverton, "Making Sense of Transnational Threats," Kent Center Occasional Papers 3:1 (2004), available at https://www.cia.gov/library/kent-center-occasional-papers/index.html.

14 Roger Z. George and James B. Bruce, Analyzing Intelligence: Origins, Obstacles and Innovations (Washington, DC: Georgetown University Press, 2008), 5.

15 Michael W. Collier, "A Pragmatic Approach to Developing Intelligence Analysts," Defense Intelligence Journal, Joint Military Intelligence College Foundation 14:2 (2005): 21.

16 Lowenthal, "The Education and Training of Intelligence Analysts," 303. 
flection. Thus, the traditional division of labor between intelligence services and universities came into question and intelligence services began assessing which role universities could play in improving their analysts. While universities were traditionally limited to providing entry-level intelligence officers, services started to see them as possible places for postgraduate education. Education was hereby viewed as one of the means to fix the lack of analytical standards blamed for intelligence failures.

Yet what could universities actually offer in terms of postgraduate education - especially if compared to in-house training, where analysts can use their own systems and classified materials? According to Goodman, academic settings offer two fundamental advantages in education when compared to closed, in-house training opportunities: their engagement in research-and thus the state-of-the art of the learning content-and the opportunity to engage with critical and unorthodox views. In the words of Frerichs and Di Rienzo, postgraduate programs can provide the "occasional shakeup in education" that is necessary if one wants to avoid "becoming locked in one epistemology, one perspective, and one approach to understanding intelligence." ${ }^{17}$ Universities provide an optimal venue for such a shakeup, and can thus play an important role for safeguarding intelligence professionals from the classical analytical traps they often ignore in their daily business. Moreover, such programs also offer fora in which officials from separate settings in the intelligence community can exchange their common understanding of intelligence. This enables these officers to reflect their own role and fosters an understanding of cooperation with other parts of the "system" of intelligence. ${ }^{18}$

\section{Curricular Approaches to Intelligence Studies}

What do such university-led programs look like in practice? This section examines how programs on the undergraduate and postgraduate level are structured in terms of curricular design, based on the review of twelve programs, whose descriptions and curricula can be found in the appendix. Secondary literature is also referenced, particularly Rudner (2008) and Landon-Murray (2013).

According to Stafford Thomas, the discipline of intelligence studies can be roughly separated into functional, historical/biographical, structural and political approaches. While functional approaches deal with fundamental capabilities, such as analysis and evaluation, historical/biographical approaches explore the history of institutions and personalities. Meanwhile, structural ap-

17 Rebecca L. Frerichs and Stephen R. Di Rienzo, "Establishing a Framework for Intelligence Education and Training," Joint Force Quarterly (JFQ) 62 (2011): 72.

18 See Michael S. Goodman and David Omand, "What Analysts Need to Understand: The King's Intelligence Studies Program," Studies in Intelligence 52:4 (2008): 1-12 (extracts, December 2008; original version classified). Cf. also Landon-Murray, "Moving U.S. Academic Intelligence Education Forward," 744-776. 
proaches examine the organization and legal framework of intelligence services, whereas political approaches instead primarily deal with the use of intelligence by policymakers and the interaction between politics and intelligence. ${ }^{19}$

As explained above, the discipline of intelligence studies has established itself primarily in the Anglosphere. Yet major differences exist even between the United States and the United Kingdom. In terms of undergraduate programs, intelligence cannot be studied as an independent program or even specialization in the UK - even though individual modules on the subject exist. On the graduate level, intelligence programs in the UK are often simply variations of broader programs in international relations. Even at institutions such as King's College, which also offers a professional development program for the British intelligence services, a master's degree in Intelligence and International Security only differentiates itself by a single compulsory intelligence-specific module from a more general degree in war studies. These focus on lessons from historical case studies - evidence to the fact that intelligence studies as a discipline in the United Kingdom emerged primarily from the study of history. ${ }^{20} \mathrm{An}$ MA in intelligence studies, according to the British model, is thus mainly an enriched master's program in international history or international relations, and concentrated on specialist knowledge. ${ }^{21}$ Even where programs have a wide intelligence curriculum, the main purpose of these classical university programs is the production of scholars on-and not practitioners in-intelligence. ${ }^{22}$

In the United States, the case is different. The structure of US undergraduate programs, which usually include the study of multiple subjects split into majors and minors, means that students can combine a minor in intelligence studies, for example, with a major in a foreign language, political science or economics. While the major thus equips students with subject matter knowledge on an issue, these intelligence studies minors often concentrate on the necessary skillsets. ${ }^{23}$ Such programs are particularly common at intelligence schools, which reflect the American tradition of professional schools, an example being schools of public service, which combine both academics and practitioners in their teaching. In the postgraduate field, programs in the US can be much more intelligence-specific than in the UK and often mirror the courses taught in intelligence studies minors. Many professional schools, which offer

19 Stafford T. Thomas, "Assessing Current Intelligence Studies," International Journal of Intelligence and Counterintelligence 2:2 (1988): 217-244.

20 Scott and Jackson, "The Study of Intelligence in Theory and Practice," 141.

21 For a more detailed description of British intelligence programs, see the program descriptions in the Appendix.

22 See, for instance, the curriculum at the University of Aberystwyth.

${ }^{23}$ For an example of a typical minor, see the program description at the University of Mississippi in the appendix. The National Intelligence University offers a similar socalled fourth year Bachelor Degree, where students bring in the equivalent of three years of education from other colleges and take only one year of intelligence-specific education at NIU. 
very well-received practitioner-oriented programs in international affairs, for example Georgetown University, also offer the same programs with an intelligence concentration. While they combine intelligence with other subjects-as in the UK-the focus on skills remains the main difference in this regard.

Postgraduate and professional education programs in both the UK and the US exist in a kind of reality of their own. Because they are aimed at intelligence officials who are already believed to be specialists with significant subject matter expertise, they avoid many pitfalls affecting undergraduate and graduate programs. Particularly the tradeoff between "specialist" and "functional" knowledge becomes less important for analysts who already possess some of both. In intelligence services institutions, such as the National Intelligence University (part of the Defense Intelligence Agency), postgraduate programs specializing on intelligence thus usually combine four features: foundations, skills, a strong study concentration and, finally, a master thesis. In their foundations, these courses mainly teach elements of international relations and security, about the role of intelligence and about the legal framework and organizational structure of the respective services. This is the spectrum that most corresponds with British programs and to what can be labelled "intelligence studies." In the skills category-the functional approach ${ }^{24}$-mainly intelligence analysis is taught, with a focus on techniques and future and scenario analysis. This spectrum corresponds mostly with courses offered at intelligence schools, but also at non-academic institutions such as CIA University. ${ }^{25}$ The aim of these modules is often less the teaching of single techniques than a better appreciation of their limits and risks. Such programs correspond with those which also the German Federal Intelligence Service teaches in other countries under the name of "critical thinking". Surprisingly, while such modules are rather ignored in British graduate programs, they are mirrored by those courses offered in professional postgraduate programs in the UK: The closed, 10-week module offered at King's College exclusively to members of the British intelligence services focuses mainly on analytical skills. ${ }^{26}$ Finally, such programs are characterized by strong and very specific study concentrations such as cyber or area studies. Aim in these concentrations is mostly an update of specialists, usually focusing on areas in which the university possesses specific strengths. ${ }^{27}$ Finally, almost all programs end with a thesis requirement - which is a noteworthy, given that American universities do not always feature thesis requirements. ${ }^{28}$

24 Thomas, "Assessing Current Intelligence Studies," 239.

25 While no detailed description is available in the unclassified domain, Lowenthal mentions the existence of such programs at CIA University. See Lowenthal, "The Education and Training of Intelligence Analysts."

26 Goodman and Omand, "What Analysts Need to Understand," 2.

27 For an in-depth discussion of U.S. intelligence curricula, see: Landon-Murray, "Moving U.S. Academic Intelligence Education Forward," 768-769.

28 International Affairs Office, U.S. Department of Education, "Structure of the U.S. Education System: Master's Degrees," February 2008, available at 


\section{An Intelligence Curriculum for German Universities}

As demonstrated throughout this paper, intelligence studies as an academic discipline and research program is focused on the intelligence aspect of other research subjects, and increasingly also on research into the professional skills required for work in the intelligence sector - especially in the sub-field of intelligence analysis. The field of intelligence studies has established itself as an increasingly common academic discipline and course program at universities, particularly in the US and the UK. This report has also argued that the subject is most suited for postgraduate professional degree programs. To preparing for a career in the intelligence services, and particularly in an analytical function, an undergraduate education that equips candidates with subject-matter knowledge is more important than training in general skills that may be required for the many diverse careers in the intelligence sector. Similarly, the training of entry-level intelligence officers is best left to the closed environments of the intelligence services, where they can train with the actual systems they will be using and have access to classified resources.

At the same time, the report also discussed that the success of intelligence studies in the Anglophone world has not met with an echo in Germany so far. While the German intelligence services have their own departments at the Federal University of Applied Administrative Sciences (Hochschule des Bundes Fachbereich Nachrichtendienste), they focus on undergraduate education for generalists in intermediate-level posts. ${ }^{29}$ To some degree, the existence of this program also precludes the necessity of similarly-structured undergraduate programs at regular public universities. In the graduate and postgraduate sectors, no similar program exists. This is particularly noteworthy as many of the reasons that have led intelligence services in the UK and US to establish postgraduate programs in recent years are also applicable Germany. Just as in these countries, most officers-particularly those in higher posts-are expected to bring the necessary skills into their service and receive little if any training afterwards (except in technical disciplines). Also in Germany, the "intelligence analyst" is a rather accidental profession. Analysts are hired for their expertise in a certain subject area-or simply assigned an analysis-stint as part of a "generalist" career-and most of the subsequent training they receive is focused on the preparation of intelligence products and the handling of databases rather than on analytical methods. Accordingly, it is very probable that common intelligence problems-such as a lack of common analytical standards-thrive also in these services.

https://www2.ed.gov/about/offices/list/ous/international/usnei/us/master.doc (accessed 15 February 2016).

29 The intermediate service (gehobener Dienst) is comparable to the warrant officers. While this corps is highly experienced and exceptionally qualified, its career scheme is limited to intermediate management (comparable to company grade officers). 
Could a professional postgraduate program in intelligence studies be established at a German university, and who would be the ideal target for such a program? It is probable that these would not be students looking for careers in intelligence, but rather mid-level intelligence officers with several years of professional experience. ${ }^{30}$ What would the curriculum of such a postgraduate professional degree program look like? Comparable programs in the UK and US focus on four aspects: basics, skills, study concentrations, and a thesis requirement. A similar structure could be followed by a German program.

A "foundations" block could look at the context in which intelligence is situated. It would typically include courses on the global political environment and the most important trends in economics and technology. It would also include, more specifically, intelligence studies-related content such as the role of intelligence among the elements of national power, as well as legal and ethical aspects of intelligence. The aim of the foundations block would thus be to introduce participants-many of whom may have been concentrating on very narrow or even niche subjects in previous years-to global, macro-level processes and their impact on intelligence and national security. Similarly, it would have them look beyond their service discipline at more general problems in the field of intelligence. By the end of this block, participants should have built a comprehensive picture of the global environment and of the role of intelligence. This block would be similar to the core curriculum at the National Intelligence University, where "the core curriculum is designed to help students develop global awareness and to understand how historical, economic, cultural, political, and social contexts affect intelligence and national security." 31

A second skills block could focus specifically on the task of analysis. Coursework would consist of structured analytical techniques, scenario and futures analysis, net assessment, and military capability analysis. The purpose of this would be to update participants' knowledge and proficiency in the most stateof-the-art methods and research in these disciplines. Perhaps more importantly, participants' engagement with researchers should increase their awareness about the inherent problems of single techniques and analytical methods. This would help them critically reflect on their professional methodology and increase their resilience against typical reasons for intelligence failure. Such a block would thus be most akin to the 10-week course for intelligence analysts offered at King's College London, or the considerable coursework on intelligence analysis offered at Georgetown or Mercyhurst University.

In the third block, the study concentration, the main purpose would be the more traditional communication of knowledge - albeit at a postgraduate level. According to their professional occupations, students could enroll in a set of

30 The comparable Master Degrees in Strategic Intelligence and Strategic and Technology Intelligence at the National Intelligence University have a median age of 37, while the King's College program is aimed at "senior analysts."

31 National Intelligence University, Academic Catalogue 2013-2014 (Washington, D.C.: National Intelligence University, 2014), 37. 
courses in subject areas focused on study concentrations, such as area studies, terrorism, or cyber. They could thus profit from discussing subjects with other subject matter experts and develop an understanding of the state-of-the-art of fields of research beyond the classroom.

The thesis would finally give students the possibility to combine the three aspects pursued as part of the program: foundations, analytical skills, and subject-matter expertise. Such a thesis would focus on aspects of relevance to the intelligence community, and could thus increase the value of the institution.

Ultimately, establishing a postgraduate intelligence studies degree program at a German university would thus be far from impossible. While much of the coursework would have to be created from scratch, such a program would also benefit from the absence of existing dominant schools and approaches in the field of intelligence studies, and could select the elements from international programs it deems most appropriate for the needs of its students.

\section{Appendix}

\section{Bachelor/Undergraduate Degrees}

- $\quad$ Bachelor in Intelligence, National Intelligence University (USA)

- Undergraduate Minor in Intelligence and International Security, University of Mississippi (USA)

- Undergraduate Major in Intelligence Studies, Mercyhurst University (USA)

\section{Graduate Degrees}

- MA in International Affairs with Intelligence Specialization, Carleton University (Canada)

- MA in Intelligence and International Security, King's College London (UK)

- $\quad$ MA in Intelligence and Strategic Studies, Aberystwyth University (UK)

- $\quad$ MA in Intelligence and Security Studies, Brunel University (UK)

- $\quad \mathrm{MSc}$ in Applied Intelligence, Mercyhurst University (USA)

- $\quad$ MA in Strategic Intelligence, Institute of World Politics (USA)

- MA in Security Studies with Intelligence Concentration, Georgetown University (USA)

\section{Postgraduate Degrees}

- $\quad \mathrm{MSc}$ in Strategic Intelligence, National Intelligence University (USA)

- $\quad \mathrm{MSc}$ in Strategic Technology Intelligence, National Intelligence University (USA) 


\section{National Intelligence University, Washington DC (USA) Intelligence \\ www.n-iu.edu}

\begin{tabular}{|l|l|}
\hline Degree & B.Sc. \\
\hline Duration & 11 Months \\
\hline Credits & 57 Credits (86-114 ECTS) \\
\hline $\begin{array}{l}\text { Curriculum / } \\
\text { Program Specifi- } \\
\text { cations }\end{array}$ & $\begin{array}{l}\text { Core Modules } \\
\text { Elective Modules }\end{array}$ \\
\hline $\begin{array}{l}\text { Entry Require- } \\
\text { ments }\end{array}$ & $\begin{array}{l}\text { Members of the U.S. Armed Forces and federal govern- } \\
\text { ment employees only, security requirements }\end{array}$ \\
\hline
\end{tabular}

Self-Description: "The National Intelligence University-previously the Defense Intelligence College-is the Intelligence Community's sole accredited, federal degree-granting institution. The Bachelor of Science in Intelligence (BSI) is a fourth-year program that affords students who have completed three years or equivalent credits ( 80 semester hours minimum) of undergraduate study a way to earn their undergraduate degree in intelligence. It is designed to encourage the development of inquiring, responsible graduates who will dedicate themselves to the improvement of the national Intelligence Community."

\section{Core Curriculum (All)}

- Globalization and the Intelligence Landscape

- Intelligence Analysis

- Collection Assets and Capabilities

- The Nature of Conflict and Conflict Capabilities

- Intelligence and National Security Strategy

- Culture and Identity in an Age of Globalization

- Science, Technology and Intelligence

- Analytic Methods

- Terrorism: Origins and Methodologies

- The Analyst-Collector Integration

- Capstone Integration

\section{Electives (Six)}

- Intelligence: Building Stability and Peace

- Introduction to Denial and Deception

- Information Operations

- Homeland Security and Intelligence

- Proliferation of Weapons of Mass Destruction 
- Africa: Intelligence Issues

- Middle East: Intelligence Issues

- Eurasia: Intelligence Issues

- Southwest Asia: Intelligence Issues

- East Asia: Intelligence Issues

- Latin America: Geostrategic Intelligence Issues

- Special Topics in Intelligence

- Europe: Intelligence Issues

University of Mississippi - Center for Intelligence and Security Studies, Oxford, MS (USA) Intelligence and Security Studies

http://ciss.olemiss.edu/the-program/courses/

\begin{tabular}{|l|l|}
\hline Degree & Undergraduate Minor \\
\hline Duration & Two Years \\
\hline Credits & 18 credits $(27-36$ ECTS) \\
\hline $\begin{array}{l}\text { Curriculum / } \\
\text { Program } \\
\text { Specifications }\end{array}$ & Core Modules \\
\hline $\begin{array}{l}\text { Entry } \\
\text { Requirements }\end{array}$ & \\
\hline
\end{tabular}

Self-Description: "The ISS Minor is designed to prepare outstanding students at the University of Mississippi for entry-level positions in the United States Intelligence Community, private industry, and public sector intelligence and security analysis. Core competencies such as engineering, critical language (e.g., Arabic, Chinese), computer and physical science, international relations, and business are highly sought after by the Intelligence Community, and students in such programs are strongly encouraged to apply to the minor. However, outstanding students from any discipline may apply for the ISS Minor."

Represented Majors are: Accountancy, Arabic, Biology, Business, Chemical Engineering, Chinese, Civil Engineering, Classics, Criminal Justice, Economics, English, French, Geology, History, International Studies, Marketing Communications, Political Science, Psychology, Public Policy, Religious Studies, Spanish.

\section{Core Modules}

- Introduction to Intelligence Studies

- Advanced Analytics I 
- Advanced Analytics II

- National Security Issues of the 21st Century

- Internship ("Senior Project: The equivalent of a senior thesis, students will apply the skills they learned in all previous courses to complete a project of practical benefit to the IC.")

Mercyhurst University - Tom Ridge School of Intelligence Studies, Erie, PA (USA)

\section{Intelligence Studies}

http://www.theridgeschool.org/academics

\begin{tabular}{|l|l|}
\hline Degree & Bachelor of Arts Major \\
\hline Duration & Four Years \\
\hline Credits & 52 credits (78-104 ECTS) (only the Major) \\
\hline $\begin{array}{l}\text { Curriculum / } \\
\text { Program }\end{array}$ & $\begin{array}{l}\text { Core Modules } \\
\text { Specifications }\end{array}$ \\
\hline $\begin{array}{l}\text { Entry } \\
\text { Requirements }\end{array}$ & Elective Modules \\
\hline
\end{tabular}

Self-Description: "It is the mission of the Tom Ridge School of Intelligence Studies and Information Science at Mercyhurst University to produce graduates, through a variety of delivery modalities, who are skilled in utilizing a variety of sources of data and analytic techniques to lead the collaborative development of high-quality written and oral analytic intelligence products that, in service toward a just world, inform decision-makers, thereby fostering an appreciation for the dignity of work and commitment to serving others.

The first non-government initiative of its kind, the Bachelor of Arts in Intelligence Studies is a unique multidisciplinary degree, which has as its goal a graduate qualified as an entry-level analyst for government and the private sector. An academically challenging discipline, it combines a liberal arts core with a foreign language or computer science requirement, national and international studies, internships, and intelligence-related courses to provide its graduates with an advanced level of analytical skills."

\section{Core Modules (AII)}

- Introduction to Intelligence Analysis

- Intelligence Methods and Analysis

- Intelligence and National Security

- Professional Communications 
- Intelligence in Business

- Writing for Intelligence

- Law Enforcement Intelligence

- Strategic Intelligence

- Advanced Computer Applications or Introduction to Data Science

\section{Language or Computer Science Concentration}

Language Option (3 Spoken Language Courses)

Computer Science Option (select three): Advanced Computer Applications, Programming, Computer Operations, Networks, Information Systems Analysis \& Design, Database Management

\section{Intelligence Electives (select three):}

- American Military History

- Intelligence, Military and Warfare

- Cultural Awareness for Intel Analysis

- Special Topics

- Improving Intelligence Analysis

- Advanced Law Enforcement Intelligence

- Cyber Threat Analysis

- Advanced Competitive Intelligence

- Terrorism

- History of Intelligence

- Internship

\section{Non-Intelligence Electives (select three):}

Five non-intelligence courses from overall course catalogue, e.g. Justice in America, Economics, History, Statistics, Geopolitics, Political Theory.

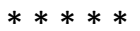

\section{Carleton University - Norman Paterson School of International Affairs, Ottawa (Canada)}

International Affairs with Specialization in Intelligence and National Security http://graduate.carleton.ca/programs/international-affairs-masters/

\begin{tabular}{|l|l|}
\hline Degree & M.A. \\
\hline Duration & Two Years \\
\hline Credits & 5.0 credits $(120$ ECTS) \\
\hline Curriculum / & Core Modules (1.5 credits) \\
\hline
\end{tabular}




\begin{tabular}{|l|l|}
\hline $\begin{array}{l}\text { Program } \\
\text { Specifications }\end{array}$ & $\begin{array}{l}\text { Specialization in Intelligence and National Security (1.5 } \\
\text { credits) } \\
\text { Language Exam } \\
\text { Thesis (2 credits) (substitutable by four additional spe- } \\
\text { cialization modules) }\end{array}$ \\
\hline $\begin{array}{l}\text { Entry } \\
\text { Requirements }\end{array}$ & Standard University Requirements, Open \\
\hline
\end{tabular}

Self-Description: "The Norman Paterson School of International Affairs (NPSIA) has been Canada's premier program in international affairs for over 40 years. We have an international reputation for providing the interdisciplinary and policy-oriented education needed to understand an increasingly complex and globalized policy environment. Our MA offers several areas of specialization focused on current world events and policy issues, including conflict management, security, terrorism and intelligence, international trade and finance, international governance and development. You will apply to one of our six fields of study, in which you can specialize, or use as a foundation for a general program combining a variety of courses that fit your interests."

Self-Description - Intelligence and National Security track: "Reviews the core theories, concepts and challenges in international security and intelligence studies in the context of applied policy problems such as terrorism, disarmament, civil-military relations and law."

\section{Core Modules (All)}

- Policy Process and International Affairs

- Law and International Affairs

- Research Design and Methods for International Affairs

- Statistical Analysis for International Affairs

- Economics for Defence and Security

\section{Specialization "Intelligence and National Security" (3 out of 7)}

- Disarmament, Arms Control and Nonproliferation

- Contemporary International Security

- Intelligence and International Affairs

- Intelligence and National Security

- National Security Policy and Law

- Terrorism and International Security

- Selected Topics in Intelligence and National Security

\section{Successful completion of second language proficiency examination}

\section{M.A. Thesis}


King's College, Department of War Studies, London (UK) Intelligence \& International Security Studies www.kcl.ac.uk/prospectus/graduate/intelligence-and-international-security

\begin{tabular}{|l|l|}
\hline Degree & M.A. \\
\hline Duration & One Year \\
\hline Credits & 180 credits $(90$ ECTS) \\
\hline Curriculum / & Core Module $(40$ credits) \\
Program & Elective Modules (80 credits) \\
Specifications & Thesis (60 credits) \\
\hline Entry & Standard University Requirements, Open \\
\hline Requirements & \\
\hline
\end{tabular}

Self-Description: "Intelligence and International Security examines the trends that continue to shape intelligence and geo-strategic developments in the $21^{\text {st }}$ century. Students will develop an awareness of the ways in which intelligence issues manifest themselves in security issues in peace and war. Understanding of ethical dilemmas associated with intelligence activity."

\section{Core Module}

- Intelligence in Peace and War

\section{Elective Modules (2 out of 34)}

- Afghan and South Asian Security Issues

- Art and War

- Civil War in the US 1861-1865

- Complex Political Emergencies, Health \& Security

- Conflict Prevention \& Peace Building

- Conflict Simulation

- Conflict, Development and Islam in Russia, the Caucasus And Central Asia

- Contemporary British Defence Policy

- Current Issues in Science \& Security

- Diplomacy

- East Asian Security

- Ethics in International Relations

- European (In)Security

- European Security

- Human Rights and Migration

- Interdisciplinary Approaches to (In)security 
- International Politics of the Middle East

- Investigating Conflict in Global Politics

- Media and Intelligence

- Missile Proliferation

- Nationalism and Security

- Natural Resources \& Conflict

- Open Source Intelligence

- Peace and Justice

- Proliferation \& International Security

- Propaganda

- Reporting Wars

- Science \& Security of Nuclear \& Biological Weapons

- Security Issues in the Soviet Successor States

- The Conduct of Contemporary Warfare

- The Evolution of Insurgency

- The JIC and British Intelligence

- The Proliferation of Weapons

- US Foreign Policy

\section{Aberystwyth University, Department of International Politics, Aberystwyth (UK) \\ Intelligence Studies (Research Training) \\ http://courses.aber.ac.uk/postgraduate/intelligence-studies-masters- specialist/}

\begin{tabular}{|l|l|}
\hline Degree & M.A. \\
\hline Duration & One Year \\
\hline Credits & 180 Credits (90 ECTS) \\
\hline $\begin{array}{l}\text { Curriculum / } \\
\text { Program } \\
\text { Specifications }\end{array}$ & $\begin{array}{l}\text { Core Modules }(80 \text { credits) } \\
\text { Elective Module }(20 \text { credits) } \\
\text { Optional Module }(20 \text { credits }) \\
\text { Thesis }(60 \text { credits })\end{array}$ \\
\hline $\begin{array}{l}\text { Entry } \\
\text { Requirements }\end{array}$ & \begin{tabular}{l} 
Standard University Requirements, Open \\
\hline
\end{tabular} \\
\hline
\end{tabular}

Self-Description: "This innovative Masters scheme is designed to facilitate the development of a critical awareness of the state of theory and practice in the field of intelligence studies in combination with an in-depth understanding of the contemporary use of force in international relations. The issues and de- 
bates explored include contending approaches and conceptual debates concerning the nature and definition of both intelligence and strategic studies, and their mutual relationship."

\section{Core Modules (AII)}

- Intelligence, Security and International Politics 1900-1945

- Intelligence, Security and International Politics since 1945

- Political, Social and Historical Research: Philosophy, Methods and Application

- Principles of Research Design

- Quantitative Data Collection and Analysis

- Qualitative Data Collection and Analysis

\section{Elective Modules (at least one):}

- Contemporary Strategic Problems Critical Security Studies

- British Counterinsurgency Warfare in the Twentieth Century

- Digital Connectivity: Digital Spaces and the Cyber Worlds

\section{Thesis}

$* * * * *$

Brunel University, Brunel Centre for Intelligence and Security Studies, London (UK)

\section{Intelligence and Security}

www.brunel.ac.uk/courses/postgraduate/intelligence-and-security-studies-ma

\begin{tabular}{|l|l|}
\hline Degree & MA \\
\hline Duration & One Year \\
\hline Credits & 180 credits $(90$ ECTS) \\
\hline $\begin{array}{l}\text { Curriculum / Pro- } \\
\text { gram Specifications }\end{array}$ & $\begin{array}{l}\text { Core Modules (120 credits) } \\
\text { Thesis (60 credits) }\end{array}$ \\
\hline Entry Requirements & Standard University Requirements, Open \\
\hline
\end{tabular}

Self-Description: "Intelligence and security policy issues are now one of the fastest growing areas of academic and public concern, especially since '9/11' and the wars in Iraq and Afghanistan. Today more than ever before national governments, international agencies and most major international corporations have an identified need for staff with a strong grasp of intelligence and security issues who can also demonstrate first-rate skills of research and assessment. 
Taught by the internationally respected scholars of the Brunel Centre for Intelligence and Security Studies, backed up where required by practitioner expertise, the MA in Intelligence and Security Studies offers a unique opportunity for practical, policy-oriented graduate study of intelligence issues applicable across the private and public sectors around the world."

\section{Core Modules (All)}

- Intelligence Concepts: Issues and Institutions

- Intelligence History: Failure and Success

- Intelligence Analysis and Decision

- Contemporary Threats and Analytical Methodology

\section{Thesis}

Mercyhurst University, Tom Ridge School of Intelligence Studies Erie, PA (USA)

\section{Applied Intelligence}

http://www.theridgeschool.org/academics

\begin{tabular}{|c|c|}
\hline Degree & M.Sc. \\
\hline Duration & Two Years \\
\hline Credits & 34 credits (51-68 ECTS) \\
\hline $\begin{array}{l}\text { Curriculum / Pro- } \\
\text { gram Specifications }\end{array}$ & $\begin{array}{l}\text { Core Modules ( } 21 \text { credits) } \\
\text { Elective Modules ( } 9 \text { credits) } \\
\text { Thesis ( } 3 \text { credits) }\end{array}$ \\
\hline $\begin{array}{l}\text { Entry } \\
\text { Requirements }\end{array}$ & Standard University Requirements, Open \\
\hline
\end{tabular}

Self-Description: "It is the mission of the Tom Ridge School of Intelligence Studies and Information Science at Mercyhurst University to produce graduates, through a variety of delivery modalities, who are skilled in utilizing a variety of sources of data and analytic techniques to lead the collaborative development of high-quality written and oral analytic intelligence products that, in service toward a just world, inform decision-makers, thereby fostering an appreciation for the dignity of work and commitment to serving others.

The Master of Science in Applied Intelligence emphasizes the application of intelligence theory across the disciplines of national security, military, law enforcement, and competitive intelligence. The Mercyhurst program focuses on intelligence as a process, using (primarily unstructured) information from all sources and focused externally, that is designed to reduce the level of uncer- 
tainty for a decision-maker. Given this focus, the coursework concentrates on developing deep researching abilities, proficient use of analytic techniques and methodologies, concise analytic writing, and effective briefing. The advancement of these analytic skills, in addition to an appreciation of the theory and history of the intelligence field, produce program graduates capable of leading in the knowledge-centric work environments of the future."

\section{Core Modules (All)}

- Research Methods in Intelligence

- Intelligence Theories and Applications

- Competitive Intelligence

- Law Enforcement Intelligence

- Intelligence Communications

- Contemporary Leadership in Intelligence

- Managing Strategic Intelligence Analysis

\section{Elective Modules (Three)}

- Advanced Analytical Techniques

- Cyber Threat Analysis

- Comparative History of Intelligence

- Intelligence Support to Targeting

- Geospatial Intelligence

- Financial Intelligence Analysis

- Intelligence and Business Strategy

- Data Analytics for the Private Sector

- Graduate Seminar: National Security

- Studies in Terrorism

- Intelligence, the Military, and Warfare

- Counterespionage and Policy and Practice

- Topics in Intelligence

- Grand Strategy: Strategic Planning \& Intelligence

- Nonproliferation Analysis

- Internship

\section{Thesis}




\section{The Institute of World Politics, Washington DC (USA)}

\section{Strategic Intelligence Studies}

http://www.iwp.edu/programs/degree/master-of-arts-in-strategic-intelligencestudies

\begin{tabular}{|l|l|}
\hline Degree & M.A. \\
\hline Duration & Two Years \\
\hline Credits & 52 Credits $(78-104$ ECTS) \\
\hline $\begin{array}{l}\text { Curriculum / Pro- } \\
\text { gram Specifications }\end{array}$ & $\begin{array}{l}\text { Core Modules }(36 \text { credits) } \\
\text { Electives/Concentrations (16 credits) } \\
\text { No Thesis }\end{array}$ \\
\hline $\begin{array}{l}\text { Entry Require- } \\
\text { ments }\end{array}$ & Standard University Requirements, Open \\
\hline
\end{tabular}

Self-Description: "The Master of Arts in Strategic Intelligence Studies is designed for students who seek careers in the intelligence field, as well as professionals whose agencies or clientele are charged with the acquisition and interpretation of intelligence. The program features courses in fundamental intelligence disciplines, such as analysis and epistemology, intelligence collection, and deception. The program equips the student with all of the requisite tools and knowledge, required and anticipated, that are necessary for professional success in the field."

\section{Core Modules (All)}

- Economics for Foreign Policy Makers

- Geography and Strategy

- American Founding Principles and Foreign Policy

- International Relations, Statecraft and Integrated Strategy

- Western Moral Tradition and World Politics

- Intelligence and Policy

- Intelligence Collection or The Role and Importance of Human Intelligence or U.S. Intelligence in the Cold War and Beyond

- Estimative Intelligence Analysis and Epistemology

- Counterintelligence in a Democratic Society

- Foreign Propaganda, Perceptions and Policy or Public Diplomacy and Political Warfare or Political Warfare: Past, Present and Future 
Elective Modules (total of four, including at least one in each specialization) Specialization in the Art of Intelligence

- American Intelligence and Protective Security: An Advanced Seminar

- Cultural Intelligence for Strategy and Analysis

- A Counterintelligence Challenge: The Enigmas and Benefits of Defectors

- Forecasting and Political Risk Analysis

- Foundations of Homeland Security

- Military Intelligence in Modern Warfare

- Surprise, Warning and Deception

- Technology, Intelligence, Security, and Statecraft

- US Nonproliferation and Nuclear Policy

Specialization in Counterintelligence and Foreign Intelligence

- Al-Qaeda's Enemy Threat Doctrine

- Case Studies in Counterintelligence Operations

- Comparative Intelligence Systems: Foreign Intelligence and Security Cultures

- Counterterrorism and the Democracies

- Cyber Statecraft

- Foundations of Homeland Security

- History of FBI Counterintelligence

- Spies, Subversion, Terrorism, and Influence Operations

- Terrorism

Georgetown University, School of Foreign Service, Washington, DC (USA) Security Studies with Intelligence Concentration https://css.georgetown.edu/ssp

\begin{tabular}{|c|c|}
\hline Degree & M.A. \\
\hline Duration & Two Years \\
\hline Credits & 36 US credits (54 - 72 ECTS) \\
\hline $\begin{array}{l}\text { Curriculum / } \\
\text { Program } \\
\text { Specifications }\end{array}$ & $\begin{array}{l}\text { Core Modules ( } 6 \text { credits) } \\
\text { Intelligence Concentration ( } 12 \text { credits) } \\
\text { Elective Module ( } 6 \text { credits) } \\
\text { Research Seminar (Thesis) ( } 6 \text { credits) } \\
\text { Exam ( } 6 \text { credits) }\end{array}$ \\
\hline $\begin{array}{l}\text { Entry } \\
\text { Requirements }\end{array}$ & Standard University Requirements, Open \\
\hline
\end{tabular}


Self-Description: "The M.A. curriculum of the Security Studies Program (SSP) is designed to give students a solid grounding in the concepts, history, and substance of national and international security problems; as well as the skills to conduct original research and analysis on contemporary security issues."

Self-Description Intelligence Concentration: "In this concentration, students acquire an understanding of the practical dimensions of intelligence, including the intelligence cycle, the intelligence disciplines, problems of intelligence collection and analysis, covert action, and the intelligence-policy nexus. Attention is also focused on domestic intelligence, military intelligence, and the intelligence operations and cultures of other countries. Students also consider major conceptual issues such as the appropriate role of intelligence in a democracy, issues of oversight and accountability, the intelligence budget as part of the overall defense budget, and the complexities of secrecy. In addition to helping students prepare for careers in the intelligence community, this concentration also addresses intelligence issues in the military, government agencies, or in government-related industries."

\section{Core Modules}

- Theory and Practice of Security

- Grand Strategy and Military Operations

\section{Intelligence - Concentration}

\section{Core Module}

- Theory and Practice of Intelligence (compulsory core)

Concentration Electives (3 out of 22)

- Comparing Intelligence Services

- Covert Action / Counterintelligence

- Disruptive Analytics: Theory, Method, \& Technology

- Key Problems in Intelligence Policy

- Thinking Critically about Intelligence and Policy

- Intelligence \& The Military

- Human Intelligence Operations

- Domestic Intelligence

- Decision-Making in Stressful Environments

- Disruptive Analytics

- Structured Analytic Techniques for Intelligence Analysis

- Security Issues in South Asia

- Security Problems in the Middle East \& Persian Gulf

- Politics of European Security

- China and Its Military 
- Security Issues in Latin America

- Power Politics in the Greater Middle East

- Warfare in the Middle East

- Eurasia \& Russia: New Security Dynamics

- Security Problems in Africa

- Globe Terrorism: Europe to Mediterranean

- Stability Challenges: South/SE Asia

Elective Modules (minimum of two)

Research Seminar (Thesis)

National Intelligence University, Washington, DC (USA)

Strategic Intelligence

www.n-iu.edu

\begin{tabular}{|l|l|}
\hline Degree & M.Sc. \\
\hline Duration & 11 months full time \\
\hline Credits & 43 Credits (70-90 ECTS) \\
\hline Curriculum / & $\begin{array}{l}\text { Core Modules (15 credits) } \\
\text { Program Requirement (3 credits) } \\
\text { Program } \\
\text { Specifications }\end{array}$ \\
\hline Entry & $\begin{array}{l}\text { Elective Modules (18 credits) } \\
\text { Thesis (7 credits) }\end{array}$ \\
\hline Requirements & $\begin{array}{l}\text { Members of the U.S. Armed Forces and federal gov- } \\
\text { ernment employees only, security requirements }\end{array}$ \\
\hline
\end{tabular}

Self-Description: "The National Intelligence University-previously the Defense Intelligence College-is the Intelligence Community's sole accredited, federal degree-granting institution. The main campus is located in Washington, D.C., but it possesses Academic Centers around the world. The Master of Science of Strategic Intelligence curriculum integrates the DNI's [Director of National Intelligence] published competencies, knowledge, and skills within the core construct of the University. Students in the degree program take the core courses to introduce students to the strategic nature of intelligence analysis. Students in the MSSI program study the human driven elements of intelligence covering political, military, economic, technical, and cultural topics as they relate to intelligence. Their thesis research must deal with a topic of importance to the IC [Intelligence Community]." 


\section{Core Modules}

- Globalization and Intelligence Issues

- Social Analysis and the Spectrum of Conflict

- Intelligence Reasoning and Analysis

- The Compound Eye: Intelligence Collection

- Intelligence and National Security Policy

\section{Program Requirement (either/or)}

- Science and Technology

- Deconstructing Strategy

\section{Elective Modules (6 total)}

Strategic Area: "Military Strategy: Intelligence in Combat and Peacetime"

- Asymmetric Warfare: Future Strategies

- Joint Campaign Planning and Intelligence

- Peacekeeping and Stability Operations

- Engaging International Partnerships

- Strategic Crisis Exercise

Strategic Area: "Intelligence Community Issues and Management"

- Leadership and Management in the Intelligence Community

- Intelligence Resource Management: Process, Politics and Money

- Ethics and Intelligence

- Intelligence and National Security

- Advancing Intelligence Collection

- Signals Intelligence Resources, Methods and Operations

- Advanced Methods of Intelligence Analysis

- Transnational Issues in a Cryptologic Environment

- Covert Action

- Current Cryptologic Issues

- Operational Capabilities Analysis

- Geospatial intelligence: Situational Awareness or Decision Advantage

- Comparative Counterintelligence Analysis

Strategic Area: "Transnational Threats: Intelligence Challenges"

- Economics and Intelligence

- Roots of Terrorism

- Transnational Threat Environment

- Intelligence to Protect the Homeland 
- Countering the Terrorist Threat

- Counterintelligence

Strategic Area: "The Geostrategic Environment: Closing Intelligence Gaps"

- Islam and the Modern World

- Africa: Geostrategic Intelligence Issues

- Northeast Asia: Geostrategic Intelligence Issues

- South Asia Intelligence Issues

- China in the Future

- Europe: Intelligence Partner and Analytic Subject

- Latin America: Geostrategic Intelligence Issues

- The Middle East: Geostrategic Intelligence Issues

- Sociocultural Intelligence

- Russia: Geostrategic Intelligence Issues

- The Caucasus

- The Near Abroad

- Iran: Geostrategic Intelligence Issues

\section{Thesis Requirement}

- Thesis Methodology and Design

- Thesis Proposal

- Thesis Research

- Thesis Completion

National Intelligence University, Washington, DC (USA) Strategic and Technology Intelligence www.n-iu.edu

\begin{tabular}{|c|c|}
\hline Degree & M.Sc. \\
\hline Duration & 11 Months \\
\hline Credits & 43 Credits (70-90 ECTS) \\
\hline $\begin{array}{l}\text { Curriculum / } \\
\text { Program } \\
\text { Specifications }\end{array}$ & $\begin{array}{l}\text { Core Modules ( } 15 \text { credits) } \\
\text { Program Requirement ( } 3 \text { credits) } \\
\text { Elective Modules ( } 18 \text { credits) } \\
\text { Thesis ( } 7 \text { credits) }\end{array}$ \\
\hline $\begin{array}{l}\text { Entry } \\
\text { Requirements }\end{array}$ & $\begin{array}{l}\text { Members of the U.S. Armed Forces and federal gov- } \\
\text { ernment employees only, security requirements }\end{array}$ \\
\hline
\end{tabular}


Self-Description: "The National Intelligence University-previously the Defense Intelligence College-is the Intelligence Community's sole accredited, federal degree-granting institution. The Master of Science and Technology Intelligence (MSTI) prepares students to recognize the impact of technological change on national security and intelligence."

\section{Core Modules (AII)}

- Globalization and Intelligence Issues

- Social Analysis and the Spectrum of Conflict

- Intelligence Reasoning and Analysis

- The Compound Eye: Intelligence Collection

- Intelligence and National Security Policy

\section{Program Requirement (either/or)}

- Advanced Methods of Intelligence Analysis

- Science and Technology

Concentration (6 courses total, four from one concentration to earn the concentration)

Concentration: "Weapons of Mass Destruction"

- WMD Terrorism

- Counter-proliferation

- The Biological Threat

- The Nuclear Threat

- The Chemical and Explosive Threat

- Advanced Conventional and Non-conventional Weapons

- Strategic Crisis Exercise

Concentration: "Information Operations and Cyber Intelligence"

- Information Power and National Security

- Propaganda, Persuasion, and Influence

- Cyber Intelligence

- Foreign Information and Cyber Strategies

- Cyber Threat

- Social Networks and Intelligence

- Advanced Information Power Seminar

- Cyber Data Exploitation and Advanced Analytics

- Network Operations Environment-Engagement

- Information Influence and Deception

- Advanced Cyber Intelligence 
Concentration: "Emerging and Disruptive Technologies"

- Advanced Science and Technology

- Advanced Conventional and Non-Conventional Weapons

- The Economics of Technology

- Case Studies in Technology Transfer

- Infrastructure Vulnerability Assessment

- Strategic Crisis Exercise

Concentration: "Geostrategic Resources and Environment"

- Intelligence and the Changing Global Resource Environment

- Geology and Intelligence

- Nuclear and Other Alternative Energy Sources

- Electrical Power Systems and Distribution

- Strategic Crisis Exercise

- The Economics of Technology

- Infrastructure Vulnerability Assessment

Concentration: "Foreign Denial and Deception"

- Introduction to Denial and Deception: History, Concepts, Issues, and Implications

- Denial and Deception: Psychological/Cultural Aspects, and National Security Decision Making

- Denial and Deception: Adversaries, Organizations, Activities, and Countermeasures

- Denial and Deception: Tradecraft, Tools, and Methodology

\section{Thesis Requirement}

- Thesis Methodology and Design

- Thesis Proposal

- Thesis Research

- Thesis Completion

\section{About the authors}

Prof. Dr. Uwe M. Borghoff is Vice President of the Universität der Bundeswehr München and Director of the Campus Advanced Study Center, the university's center for professional education. Dr. Brigita Jeraj and Alessandro Scheffler Corvaja are an Executive Assistant and a Research Associate at the Campus Advanced Study Center. 


\section{Bibliography}

Collier, Michael W. "A Pragmatic Approach to Developing Intelligence Analysts." Defense Intelligence Journal, Joint Military Intelligence College Foundation 14, no. 2 (2005).

Fishbein, Warren, and Gregory Treverton. "Making Sense of Transnational Threats." Kent Center Occasional Papers 3, no. 1 (2004), https://www.cia.gov/library/kent-center-occasional-papers/index.html.

Frerichs, Rebecca L., and Stephen R. Di Rienzo. "Establishing a Framework for Intelligence Education and Training." Joint Force Quarterly (JFQ) 62 (2011).

George, Roger Z., and James B. Bruce. Analyzing Intelligence: Origins, Obstacles and Innovations. Washington: Georgetown University Press, 2008.

Goodman, Michael S., and David Omand. "What Analysts Need to Understand: The King's Intelligence Studies Program." Studies in Intelligence 52, no. 4 (2008).

Johnson, Loch J., and Allison M. Shelton. "Thoughts on the State of Intelligence Studies: A Survey Report." Intelligence and National Security 28, no. 1 (2013).

Krieger, Wolfgang. "German Intelligence History: A Field in Search of Scholars." Intelligence and National Security 19, no. 2 (2004).

Landon-Murray, Michael. "Moving U.S. Academic Intelligence Education Forward: A Literature Inventory and Agenda." The International Journal of Intelligence and Counter Intelligence 26, no. 4 (2013).

Lowenthal, Mark M. "The Education and Training of Intelligence Analysts." In Analyz-ing Intelligence: National Security Practitioners' Perspectives . Roger Z. George and James B. Bruce ed. Washington: DC: Georgetown University Press, 2014.

Marrin, Stephen. Improving Intelligence Analysis: Bridging the Gap Between Scholarship and Practice. London: Routledge, 2011.

Office, U.S. Department. Structure of the U.S. Education System: Master's Degrees, 2008, https://www2.ed.gov/about/offices/list/ous/international/ usnei/us/master.doc.

Rudner, Martin. "Intelligence Studies in Higher Education: Capacity-Building to Meet Societal Demand." International Journal of Intelligence and CounterIntelligence 22, no. 1 (2008).

Scott, Len, and Peter Jackson. "The Study of Intelligence in Theory and Practice." Intelligence \& National Security 19, no. 2 (2004).

Smith, Jonathan. "Amateur Hour? Experience and Faculty Qualifications in U.S. Intelligence Courses." Journal of Strategic Security 6, no. 3 (2013). 


\section{Corvaja, Jeraj, \& Borghoff, Connections QJ 15, no. 1 (2016): 79-106}

Thomas, Stafford T. "Assessing Current Intelligence Studies." International Journal of Intelligence and Counterintelligence 2, no. 2 (1988). 